\title{
Feyerabend's Humanitarianism: Considerations on Feyerabend's Moral Relativism
}

\author{
Mohsen Khademi ${ }^{1}$ \\ ${ }^{1}$ Philosophy of Science Group, Amirkabir University of Technology, Tehran, Iran \\ Correspondence: Mohsen Khademi, Philosophy of Science Group, Amirkabir University of Technology, Tehran, Iran.
}

Received: August 10, 2016

Accepted: November 15, 2016

Available online: December 20, 2016

doi:10.11114/ijsss.v5i1.2090

URL: http://dx.doi.org/10.11114/ijsss.v5i1.2090

\begin{abstract}
My paper is split into five sections. After a rather briefly preface as to how the modern science did outdistance the other rivals after the scientific revolution, in the second section I shall go over Feyerabend's diatribe against "authority of scientific knowledge", "tyranny of science", and the reason why he has denied the authority. According to him, "science has now become as oppressive as the ideologies it once had to fight." Hence it can no longer be the neutral judge of human activities. The third section, being a direct consequence of the first section, is some considerations on Feyerabend's humanitarianism. In this section I argue that Feyerabend substituted human-being/ humanitarianism in the place of science/ scientific criteria. Because, for him, humanitarianism is far preferable to scientific standards and values. This shows that epistemic relativism doesn't necessarily lead to thorough-going moral-political relativism which, in turn, eventuates in anarchism. He even went so far as to base his neutral utopian society on humanitarianism- one which cannot be based on humanitarian considerations! In fourth section I shall proceed to the paradox. And finally, in the last section, expressing a key point in some detail, I shall show that, according to Feyerabend, relativism isn't egalitarianism at all, but rather humanitarian considerations are the center of gravity of his relativism. On this ground, he would distinguish "proper behavior" from "improper". By the same token, methinks, he is to be considered as a moderate moral relativist, not as a full-blown moral relativist. In a nutshell, a central aim of this paper is to assist the reader of Feyerabend to grasp the main idea of his philosophy from an entirely new perspective.
\end{abstract}

Keywords: Paul K. Feyerabend, humanitarianism, relativism, the Medieval Church

\section{Introduction}

As prolegomena, let me begin with a rather briefly preface. The scientific revolution was the harbinger of putting sovereign of science on the throne. Thereafter science became increasingly pompous. It was, of course, not without good reason. Science took great steps, outrunning all its rivals. It could treat forms of illness that for earlier generations might have seemed to be maladies without a cure. Spacecraft, submarine, electronic means and the like are all greatly beholden to modern science.

On this subject, scientific innovations and discoveries in the seventeenth century, not only in physics, astronomy but in biology, dynamics and pure mathematics was marvelous. ${ }^{1}$ From that time down to the twentieth century, even prominent thinkers, though they might complain of science, were, in the main, not crucial critics, bowing to the judgment of science, revering it as a hero, putting it on a pedestal, seldom questioning its authority. In short, science so captured hearts and minds that an appeal to scientific knowledge was considered as a leading brand.

But the twentieth century was the declaration of the end of believing in the neutrality, authority of science. In spite of the fact that science in the century gained distinguished achievements- such as Einstein's special theory of relativity (1905) and general relativity (1915), Hubble's law (on the expansion of the universe) (1929), discovery of DNA (1953),

\footnotetext{
${ }^{1}$ To exemplify what I mean, let us look at some results of this century: in astronomy and dynamics: innovation of barometer, thermometer, air pump, microscope, telescope; in physics and biology: Gilbert's theory of magnetism, Boyle's law, Harvey's theory of blood circulation, and the discovery of unicellular organisms and bacteria; and in pure mathematics: invention of logarithms, co-ordinate geometry, and the differential and integral calculus. On the subject of a detailed account of these innovations, see the chapter 'Scientific Instruments' in A History of Science, Technology, and Philosophy in the Sixteenth and Seventeenth Centuries, by Abraham Wolf.
} 
Moon landing (1969), nuclear fission (1938), the world's first successful human-to-human heart transplant (1967)- but the downside was that it was entwined with technology and politics and engendered irreparable damage, some of which are: confirming Mendelian genetics (1900) and thereupon reviving Galton's idea on improvement of the races ${ }^{2}$ and its disastrous consequences, compulsive sterilization and involuntary euthanasia included, the World Wars I (1914), the World Wars II (1939) and atomic bombings of Hiroshima and Nagasaki (1945) which announced the end of the war, the Green Revolution (1930s-1960s) and thereby producing some sort of chemical materials and, at the end, the Chernobyl disaster (1986). The cases, of course, are a foretaste of things to come. The consequence of the achievements and events was that the viewpoint of bold thinkers was completely transformed, and gradually crucial critics of science appeared. They realized that science is a double-edged sword. It is a medicine that both treats one disease and, at the same time, begets several other diseases. It can both bring forth human welfare and produce the nuclear weapons or hydrogen bombs that raze the world to the ground. The two-sided features, effects prompted sociologists, historians, philosophers of science and feminists to scrutinize science. The "Science Wars", which took place in the 1990s, is a good example of the intellectual challenges to the authority of science in the academic circles. Feyerabend, like other eminent thinkers, not being as entranced, blinded by the slogans, would always try to show that the science most people buy and bow is a pig in a poke. In next section I propose to reconstruct Feyerabend's criticisms of modern science. I therefore want the reader to bear with me when I explain Feyerabend's biting criticism in some detail.

\section{Science as the Medieval Church}

According to Feyerabend, modern science has a lot in common with the Medieval Church. He would maintain that nowadays science has been turned into a rigid religion whose prophets are scientists, whose miracles scientific discoveries and whose judgements scientific statements. ${ }^{3}$ Roughly speaking, modern science is the Christian religion in disguise. Why did he ascribe to modern science a religious ideology? Why did he say "science has now become as oppressive as the ideologies it once had to fight"? (1999b, p182) To answer the questions we need only remember how the rigid church had treated in the Middle Ages.

First of all, consider the role science now plays in education. "Scientific 'facts' are taught at a very early age and in the very same manner in which religious 'facts' were taught only a century ago. There is no attempt to waken the critical abilities of the pupil so that he may be able to see things in [historical] perspective. At the universities the situation is even worse, for indoctrination is here carried out in a much more systematic manner." (1999b, p182) Besides, "almost all scientific subjects are compulsory subjects in our schools... Physics, astronomy, history must be learned; they cannot be replaced by magic, astrology, or by a study of legends." (SFS, p74) This is only one case. Broadly speaking, modern science, in common with the rigid church in the Middle Ages, presides over all human affairs such as: "education programs", "religious instruction", "proposals for prison reform", "army training", even over "human relations" and "important political, democratic decisions" and so on and so forth. ${ }^{4}$

On the other hand, "in society at large the judgement of the scientist is accepted with the same reverence as the judgement of bishops and cardinals was accepted not too long ago." (1999b, p182) Or, even worse, it is received in advance "without having examined them, and without having subjected them to a vote." (SFS, p74)

Most importantly, in the modern science there's an unwritten law to the effect that "what is compatible with science should live, what is not compatible with science, should die". (AM, p36) ${ }^{5}$ The announcement of the unjust, tyrannical rejection of astrology, which was published in the September/ October issue 1975 of the Humanist, is an excellent examples of the feature I have just described. In that year, in order to determine the fate of astrology, 186 leading scientists got together. ${ }^{6}$ But, what did they really know about astrology? The answer is that "they know a few phrases which sound like arguments, but they certainly do not know what they are talking about." (SFS, p91) There is a concrete evidence for this claim: "when a representative of the BBC wanted to interview some of the Nobel Prize Winners they declined with the remark that they had never studied astrology and had no idea of its details." (ibid,

\footnotetext{
${ }^{2}$ As an example: The Eugenics Education Society (1907) in London and The Eugenics Record Office (1910) in American.

${ }^{3}$ See: SFS, pp73-4. All references are to Feyerabend unless otherwise stated.

${ }^{4}$ See: SFS, p74

${ }^{5}$ Of course, Feyerabend himself refers to: Chou Shao, 1933, as quoted in Croizier, op. cit., p. 109. Cf. also D.W.Y. Kwok, Scientism in Chinese Thought, New Haven, 1965.
}

${ }^{6}$ See full text of the Statement: "Objections to Astrology: A Statement by 186 Leading Scientists". The Humanist, September/October 1975. Archived from the original on 18 March 2009. The Humanist, volume 36, no.5 (1976) 
footnote) And as Feyerabend would say, "the religious tone of the document", "the illiteracy of the 'arguments' and "the authoritarian manner" of these scientists are all tantamount to the religious tone of the Malleus Maleficarum [The Hammer of Witches], the outstanding treatise on the prosecution of witches, and have unpleasant associations for us. The treatise, first published in 1486, has a bull by Pope Innocent VIII. The bull reads: "It has indeed come to our ears, not without afflicting us with bitter sorrow, that in ...'- and now comes a long list of countries and counties- 'many persons of both sexes, unmindful of their own salvation have strayed from the Catholic Faith and have abandoned themselves to devils ...' and so on. The words are almost the same as the words in the beginning of the 'Statement', and so are the sentiments expressed. Both the Pope and the ' 186 leading scientists' deplore the increasing popularity of what they think are disreputable views" (SFS, p92) and reject them pitilessly- the former is owing to religious heresy, and the latter to "scientific heresy" .

Even, by taking all these considerations into account, if the chauvinist of science has not become still convinced of the churchlike dogmatism of modern science, "let us ask whether they would be prepared to give, say the views of the Hopi, the same role in basic education which science has today, let us ask a member of the AMA whether he would permit faith-healers into state hospitals"? (SFS, p76) Obviously, the answer is an unequivocal 'No', or in the most optimistic state, no answer is forthcoming. And the very same is the dictatorship of science.

Another resemblance between science and church is that scientists, like priests, claim unequivocal discovery of truth. In answer to the claim, Feyerabend would say that firstly "'truth' is such a nicely neutral word." (1999b, p182) It is we (our traditions) who (which) give a meaning to "philosophical obfuscators and abstract concepts such as 'truth', 'reality', or "objectivity". ${ }^{8}$ Secondly "it [the appeal to the discovery of truth] is used whenever an ideology wants to reinforce the faith of its followers." (ibid) Furthermore, if we look very carefully in the word, i.e. Truth, we will realize that "allegiance to truth" is in sooth "allegiance to the Truth of an ideology". Most especially, granted that 'truth' is in the hands of an ideological tradition, does it follow that its ideology must be imposed on everyone/ every tradition? Mainly why must we give in 'truth'? "Human life is guided by many ideas. Truth is one of them. Freedom and mental independence are others. If Truth, as conceived by some ideologists, conflicts with freedom then we have a choice. We may abandon freedom. But we may also abandon Truth."(ibid, p183)

Certainly, most science-struck people refuse point-blank to accept the churchlike characteristic of science. They take refuge in the achievement of science, saying science, because of its achievements, is praised. On the other hand, the scientist in the same trench takes two arguments from his arsenal of arguments: result and method. In other words, they suggest that science, being resultful and methodic, is far preferable to other alternatives. But, Feyerabend would take issue with those who hold this, giving both answers.

In reply to the former, i.e. result, Feyerabend, in common with Husserl, holds that "the only reason we [i.e. laymen] are tempted to embrace "scientism" and to deify science in this way is because we are so impressed by its successes." (Russell, 2006, p181) However "this is an [excellent] argument only if it can be shown (a) that no other view has ever produced anything comparable and (b) that the results of science are autonomous, they do not owe anything to non-scientific agencies."(SFS, p100) Let us not forget that man's greatest inventions, i.e. "fire" and "wheel", "highly developed cosmologies", "medical theories", "biological doctrines", "domesticating animals", "breeding new types of plants" and so forth are all beholden to "our "primitive' ancestors" and "inventors of myth". "Mechanics and optics owe a lot to artisans, medicine to midwives and witches, Copernicus to a crazy Pythagorean such as Philolaos." (1999b, p186) Roughly speaking, "there is not a single important scientific idea that was not stolen from elsewhere." (SFS, p105) If modern science has seen further it is by standing on the shoulders of earlier traditions. Hence "if science is praised because of its achievements, then myth must be praised a hundred times more fervently because its achievements were incomparably greater." (SFS, p104)

Feyerabend points out, in reply to the latter, that studies show that science is too garbled to be cast by certain well-defined methods, the scientist is too human-being to operate machinelike, and also, natural phenomena and environmental factors are too indomitable to have great respect for reason, to act according to the command of reason forever. Besides, history of science indicates that there are too non-methodical successes and methodical failures to

\footnotetext{
${ }^{7}$ See: Feyerabend, 1999b, p182. Where he would say "Do not be misled by the fact that today hardly anyone gets killed for joining a scientific heresy. ... Heretics in science are still made to suffer from the most severe sanctions this relatively tolerant civilization has to offer." (ibid)

${ }^{8}$ In killing time Feyerabend writes: "One of my motives for writing Against Method was to free people from the tyranny of philosophical obfuscators and abstract concepts such as 'truth,' 'reality,' or 'objectivity,' which narrow people's vision and ways of being in the world. (1995a, p179)
}

${ }^{9}$ Cf. SFS, p104. 
elicit a unique, universal method from the sporadic successes and failures. ${ }^{10}$ In one word, history of science is a repository of exceptions, it cannot be elicited rules from exceptions. For these reasons, there is not "a universal and stable method" that remains valid under all circumstances, because "science is an essentially anarchic enterprise" (AM, p9) and so in the realm of science "anything goes". (ibid) ${ }^{11}$

From what has been said hitherto about Feyerabend's views on science, it might seem as though he was against modern science. It is, of course, easy to misrepresent him by one-sided quotations. But mere misunderstanding, I suspect, makes someone suppose that he was an enemy of science. As a matter of fact he felt no animosity towards science and had no quarrel with scientists. ${ }^{12}$ His real opponent was "technocracy" ${ }^{13}$ and "chauvinism of science". For him, "the chauvinism of science is a much greater problem than the problem of intellectual pollution." (AM, p163) Criticizing modern science Feyerabend was only going to revive a "humanitarian science": the more humanitarian the better.

However, what the above arguments amount to is that:

Corollary1: Neither science nor scientist must be deified by men. "Scientists are salesmen of ideas and gadgets, they are not judges of Truth and Falsehood. Nor are they High Priests of Right Living." (1980, p15) "Scientists are no better off than anybody else... they only know more details." (AM, p2)

Corollary2: Science is not preferable to any tradition.

Corollary3: Neither science, and a fortiori, nor any tradition can be the neutral judge of human activities.

These considerations and such like- combined, of course, with the idea of incommensurability, and also social-anthropological studies- propelled him to a version of relativism, but not one based on truth and falsehood. It is "about human relations not about concepts". (FR, p83) Feyerabend called his position 'democratic relativism'. He made clear-cut distinction between "political relativism" and "philosophical relativism". The former is the doctrine that "all traditions have equal rights". (SFS, p82) The latter "is the doctrine that all traditions, theories, ideas are equally true or equally false or, in an even more radical formulation, that any distribution of truth values over traditions is acceptable." (ibid, p83) According to Feyerabend, "a [true] relativist who deserves his name will have to refrain from making assertions about the nature of reality, truth and knowledge". (FR, p78) And, in one word, "relativism, in Feyerabend's hands, is not so much a philosophical doctrine to be judged as true or false, but a method for dealing with cultural and individual differences. It is a plea for intellectual and political tolerance and a denunciation of dogmatism." (Baghramian, 2004, p146) "It says that what is right for one culture need not be right for another (what is right for me need not be right for you)." (FR, p85) On this ground, the present paper is mainly directed to Feyerabend's beloved relativism.

However, I have dealt hitherto only with negative sides of Feyerabend's ideas. It is time now to examine its positive sides. Feyerabend, who was as likely as not cognizant of potential anarchism of his ideas, believed that a criterion must be found of adjudicating between different traditions. Because, as long as there is no neutral authority to decide disputes between traditions, every tradition is the judge in its own cause. In order to overcome this evil, Feyeabend propounds a criterion by virtue of which can choose between different things. To drive the point home I shall discuss it further in the next section.

\section{Humanitarian Considerations: Preference Criterion}

In what follows I shall try to show that fundamental criterion behind Feyerabend's arguments is only one thing: "humanitarian considerations". ${ }^{14}$ The vestige of the considerations can nearly be seen in his whole ideas- from his

\footnotetext{
${ }^{10} \mathrm{Cf}$. Feyerabend, AM, p9

${ }^{11}$ To my knowledge, the incontestable validity of scientific method, which was once a battlefield of ideas, was wounded by Kuhn, Lakatos struggled to come to its rescue, but soon it proved to be a flash in the pan, and eventually it was entombed by Feyerabend. An extended explanation of his elegy for scientific method can be seen in his epoch-making book entitled Against Method.

${ }^{12}$ As an example see this words: "I am not against a science so understood. Such a science is one of the most wonderful inventions of the human mind. But I am against ideologies that use the name of science for cultural murder." (AM, p4) "Nor am I asserting that we can do without the sciences. We cannot." (FR, p89) "My criticism of modern science is that it inhibits freedom of thought." (1999b, p183)

${ }^{13}$ Cf. Paul Feyerabend, Democracy, Elitism, and Scientific Method, Inquiry 28 (1980)

${ }^{14}$ It doesn't, of course, mean that he doesn't allege historical-philosophical arguments, but rather it means that he first assays humanitarian carat of something. If it is satisfactory then all is well, if not, he strongly disagrees with it. Now, it
} 
methodological ideas and prescriptions down to social-political ones. In general, humanitarian considerations are be-all and end-all of Feyerabend's philosophy. Be that as it may, what he means by "humanitarianism" is to be gathered from his whole books. To the best of my knowledge, by the term he means the cases such as "right to life", "equal rights", "carelessness and inattention", "avoidance of violence", "tolerance", "liberty" 15 , "freedom of thought", "respect for the individual, traditions" and such like. A few quotations will make this clear.

Feyerabend states implicitly that "humanitarian considerations" such as "tolerance" and "same rights" are touchstone of the progress of human societies. Where it is said: in the past "tolerance of different traditions and different creeds was considerable and by far exceeded the tolerance which Christians later showed towards alternative forms of life. The Yassaq of Genghis Khan which proclaims the same rights for all religions shows that history does not always progress and that the 'modern mind' may be far behind some 'savages' as regards reasonableness, practicality and tolerance." (SFS, p85)

According to Feyerabend, humanitarian considerations can even be applied to the situation in a case of war: "In a war a totalitarian state has a free hand. No humanitarian considerations restrict its tactics ... [While] a democracy, on the other hand, is supposed to treat the enemy in a humane fashion even if this should lower the chances of victory... . We must realize that there are more important things in this world than winning a war, advancing science, finding the truth." (SFS, p87)

But what does he mean by "more important things"? The answer to the question, in so far as I am capable of giving it, is cases such as breeding "citizen initiatives" (AM, p229), "human attitude" (SFS, p87), "dignity and happiness" (FR, p319), even "a faint smile" (SFS, p122), and above all "love" (KT, p181). As he says quite explicitly that "my concern is that after my departure something remains of me, not papers, not final philosophical declarations, but love". (KT, $\mathrm{p} 181)^{16}$ or where it is said "bringing a faint smile to the faces of people who have been hurt, disappointed, depressed, who are paralysed by some 'truth' or by the fear of death seems to me an achievement infinitely more important than the most sublime intellectual discovery." (SFS, p122)

On such ground, for him, practicing an art is far preferable to philosophizing. He himself says on this subject: "enriching and changing knowledge, emotions, attitudes through the arts now seems to me a much more fruitful enterprise and also much more humane than the attempt to influence minds (and nothing else) by words (and nothing else)." (SFS, p114) and that is why, "compared with poetry and common sense, philosophical discourse is barren- and insensitive." (2001, p270)

All the same, the story does not end here. Feyerabend speaks repeatedly of "humanitarian considerations". He is of opinion that these must be preserved at the expense of everything else. The very same is true of his methodological approach. To put it another way, Feyerabend's methodological approach is based on "humanitarianism" as well. On this ground, he opposes clearly universal rules and methods, because they will reduce "our humanity" by increasing our professional qualifications. He argues that "the idea that science can, and should, be run according to fixed and universal rules, is both unrealistic and pernicious. ... It is pernicious, for the attempt to enforce the rules is bound to increase our professional qualifications at the expense of our humanity." (AM, 1975, p. 295) Or where he prefers "methodological pluralism" to "methodological monism": "17 "Pluralism of theories and metaphysical views is not only important for methodology, it is also an essential part of a humanitarian outlook." (AM, p38) "And a method that encourages variety is also the only method that is compatible with a humanitarian outlook." (AM, p32) ${ }^{18}$ Additionally, the main reason why Feyerabend defends "theoretical anarchism" is that it is in harmony with his humanitarian attitude.

may occur to someone that, if so, why doesn't he disagree with Cannibals, Nazists and those who want to "realize themselves only by killing their fellow human beings"? The answer to the question will delay up to the next section.

${ }^{15}$ Of course, it should be observed that liberty in "Free Society" isn't absolute liberty, that is to say, any one does whatsoever he pleases, but rather it is Millian liberty. Most especially, Feyerabend himself says "absolute liberty is an abstraction not found in this world but that conditional liberty is possible, desirable, and should be sought."'(SFS, p174)

${ }^{16}$ Even, in an interview, Feyerabend said: "If my love for these people [particular my wife, and my close friends] is strong enough it will be capable of including everybody and, in the last resort, every living thing. [Interviewer asked:] Also Hitler? [And Feyerabend, much to the consternation of everyone, said:] Certainly also Hitler." (Beyond Reason, p521)

${ }^{17}$ Of course, Feyerabend would always defend "pluralism"- whether "methodological pluralism" or "political pluralism".

${ }^{18}$ Also cf. Feyerabend, 1999b, p5. Certainly, "[his] objections to theoretical monism are ultimately based on humanitarian ethical values." (ibid) 
For him, "theoretical anarchism is more humanitarian and more likely to encourage progress than its law-and-order alternatives." (AM, p9)

More wondrous, in the last book of the Conquest of Abundance, which unluckily did not live to complete it, Feyerabend went one step further, saying forms of life can be taken as a measure of reality. In general, " "real" is what plays an important role in the kind of life one wants to live," says he. (2001, p248) Even he regarded "ethics as a measure of scientific truth". The gist of his argument, whether true or false, is that since ethics surreptitiously affects scientific ontology, it can be a measure of scientific truth. To make this clearer I'd like to relate his whole quotation- just to be on the safe side:

"The predicate "real," is only apparently descriptive. Reflecting a preference for forms of coherence that can be managed without too much effort, it contains evaluations, though implicit ones. Now wherever there is a preference there can be, and perhaps should be, a counter-preference. For example, we may emphasize human freedom over easy manageability. This means, of course, that ethics (in the general sense of a discipline that guides our choices between forms of life) affects ontology. It already affected it, in connection with the sciences, but surreptitiously, and without debate. To start the debate we must insert our preferences at precisely those points that seem to support a scientific worldview; we must insert them at the division between what is real and what does not count. And as this division constitutes what is true in science and what is not; we can say that ethics, having once been a secret measure of scientific truth, can now become its overt judge." (2001, p247)

I have hitherto, I think, shown that humanitarian considerations are Feyerabend's touchstone by virtue of which can choose between different traditions/ theories/ ideas. Not only are these, for him, touchstone of the progress of human societies, but are even touchstone of scientific truth. On such ground, practicing an art is, for him, far preferable to philosophizing, even to practicing science. Small wonder, "Nestroy, George S. Kaufman, Aristophanes, on [his] scale of values range [are] far above Kant, Einstein and their anaemic imitators." (SFS, p122)

Again, on the basis of the same attitude, Feyerabend, in common with Kant's end-based ethics, ${ }^{19}$ doesn't hold to be treated other traditions, individuals as a means to achieving what we want. Hence he gives a precept to us to respect other traditions, individuals regardless of their advantages: "We should respect their ways even if they should turn out to be absolutely useless for the rest of society." (F.R, p40) ${ }^{20}$ Out of the very same considerations he would say: "My concern is neither rationality, nor science, nor freedom ${ }^{21} \ldots$ but the quality of the lives of individuals." (F.R, p17) "I am thinking of the women's movements, gay liberation, ecological groups, and so on." (1980, p11) "I write ... for all the people who despite hunger, oppression, wars try to survive and to achieve a little bit of dignity and happiness." (F.R, 318-19) In Science in a Free Society he, having criticized science, makes his blood boil, launching into a diatribe on the transgression of humanitarianism: "I do not see why I should be polite to tyrants, who slobber of humanitarianism and think only of their own petty interests." (SFS, p136) There's no end to comments of this kind for us to marshal. You need only flip one or two of his works. ${ }^{22}$

\section{Humanitarianism: Paradox of Feyerabend's Utopia}

Feyerabend goes so far as to fall unwittingly into the trap of paradox in the doctrine of "Free Society". It is, of course, so natural; no one has yet succeeded, in Russell's words, in inventing a philosophy at once credible and self-consistent. Let us now examine this paradox. For his utopia- based on three fundamental isms: 'Anarchism, Pluralism,

\footnotetext{
${ }^{19}$ As you know, Kant held that we should treat other people as ends in themselves and Feyerabend would always say that "My suggestion [is] to regard all traditions as being intrinsically valuable." (Beyond reason, p 519), my italics.

${ }^{20}$ Here, Feyerabend himself refers to Kant's categorical imperative in "Groundwork of the Metaphysic of Morals": "Kant's request to treat (each part of) humanity as an end, never as a mere means: "Act in such a manner that you regard humanity both in your own person and in the person of others always also as an end, and never merely as a means" (Grundlegung der Metaphysik der Sitten, 1786 (edition B), pp. 66f.)."

${ }^{21}$ The reason why Feyerabend mentions "freedom" is that he holds that it isn't problem for all traditions. By the same token, "I do not favour the export of 'freedom' into regions that are doing well without it and whose inhabitants show no desire to change their ways." says he. (FR, p39)

${ }^{22}$ For more examples, see: SFS, p176; AM, p252, FR, p77. "The occasional violence of his arguments" must be comprehended in the light of the transgression of humanitarianism and ethics.
} 
Democratism ${ }^{, 23}$ - Feyerabend propounds features that the most characteristic ones are as follows:

i. $\quad$ A free society is a society in which all traditions are given equal rights, equal access to education and other positions of power. (AM, p228)

ii. A free society cannot be based on any particular creed; for example, it cannot be based on rationalism or on humanitarian considerations. (ibid)

iii. A free society will not be imposed but will emerge only where people solving particular problems in a spirit of collaboration introduce protective structures of the kind alluded to. (ibid, p229)

$i v$. The debates settling the structure of a free society are open debates not guided debates. (ibid)

Feyerabend, in speaking of significant features of "Free Society", expresses that "it cannot be based on humanitarian considerations." But why does he point it out? Why need he say that? Why cannot it be based even on humanitarian considerations which are his beloved criteria? The answer is right under our noses. Feyerabend holds that all men, even "Taoists, Cannibals, Racists, Nazists", are created equal, there are no essential differences among men with regard to their being human beings and their having human rights. Furthermore, in a "Free Society" everyone should have the right to live as he sees fit. ${ }^{24}$ "Free Society" requires equal treatment for all traditions, regardless of religion, race, or advantages. The very same is true of those who want to "realize themselves only by killing their fellow human beings". (SFS, p132) According to Feyerabend, whether true or false, "whoever wants to lead a dangerous life, whoever wants to taste human blood will be permitted to do so within the domain of his own subsociety. ${ }^{25}$ But he will not be permitted to implicate others who are not willing to go his way."(ibid) By stipulating so, Feyerabend can both come true his dream, i.e. observing some humanitarian considerations - such as giving the right to life, freedom- and don't fall into the trap of the criticism of "tyranny of the majority". It is so evident that if "Free Society" must be entirely based on humanitarian considerations, then it is to be got rid of most non-humanitarian traditions, groups of individuals mentioned above. But it isn't his cup of tea, since it isn't in harmony with his humanitarian attitude. This is, therefore, the main reason why he introduces the feature. But, further thought shows that the very same feature (F.ii) is a kind of humanitarian considerations; because, as to the feature all groups of individuals have the right to live as they see fit, merely owing to their being human-beings and nothing else. This is a paradox in Feyerabend's utopia: A society which can't be based on humanitarian considerations, while at the same time, gives the right to life to other non-humanitarian traditions! What the feature (F.ii) amounts to is that the right to life is the most basic humanitarian principle of "Free society".

Similarly, if you take a closer look at other features, you will notice that all of the features- giving equal rights (F.i), being optional of the society; that is to say, freedom of choice (F.iii) and being open debates, i.e. participating in each other's ways of thinking, feeling, perceiving and respecting the partner ${ }^{26}$ (F.iv) and even its fundamental isms- are all based tacitly on one criterion: humanitarian considerations. In one word, there's no escaping the fact that, in Feyerabend's utopia, humanitarian considerations are both necessary and inevitable, since it is the only way that he can retain all non-humanitarian traditions.

In addition to the paradox, still more surprising is that he, who is in disagreement with presenting general, universal

\footnotetext{
${ }^{23}$ It is, of course, to be noted that by the terms 'Anarchism and Democratism' he respectively means the "anarchism" based on "the cultivation of individuality", and "direct democracy" in which people decide policy activities directly. (As an example See: FR, pp 52, 62; SFS, p87 or 1980, p16)

${ }^{24} \mathrm{Cf}$., SFS, pp119, 138, and 176.

${ }^{25}$ I think, Feyerabend has taken the idea of "sub-society" form Mill's "immortal essay On Liberty". (SFS, p86) This idea is, in turn, based on the right to life: Every human-being has the inherent right to life. Therein, Mill clearly states that Mormonism is "the product of palpable imposture, not even supported by the prestige of extraordinary qualities in its founder". (Mill, 2003, p153), adding that "No one has a deeper disapprobation than I have of this Mormon institution."(ibid, p.154) For, it is a direct infraction of principle of liberty. But "when they have left the countries to which their doctrines were unacceptable, and established themselves in a remote corner of the earth... it is difficult to see on what principles but those of tyranny they can be prevented from living there under what laws they please, provided they commit no aggression on other nations, and allow perfect freedom of departure to those who are dissatisfied with their ways." (ibid, p154)

${ }^{26}$ Note that, according to Feyerabend, "An open exchange is guided by a pragmatic philosophy. The tradition adopted by the parties is unspecified in the beginning and develops as the exchange goes along... An open exchange respects the partner whether he is an individual, or an entire culture." (SFS, p29)
} 
principles, shows his hand and, following Mill, introduces one general principle in a free society: ${ }^{27}$ "There are no general principles apart from the principle of minimal interference with the lives of individuals, or groups of individuals who have decided to pursue a common aim." (SFS, p132) Needless to say, this general principle is also based on humanitarianism.

\section{A Considerable Distinction}

I come now to the conclusion of the above discussion. But, before making an inference, let me proceed to one pointwhich we shall do well to dwell upon it for a moment. Roughly speaking, the relativist, as I shall understand the word, holds that: firstly there is no absolute, universal, ahistorical standard. All things are relative and hence all judgments are context-dependent. Consequently and secondly one theory, paradigm, or tradition can't be judged better than another. In one word, all theories are on a par. In Nozick's words "relativism is egalitarian". (Nozick, 2001, p19)

As to this elucidation, if true, I first distinguish between Universal Preference Criterion (UPC) and Local Preference Criterion (LPC). The former is a criterion to be beyond traditions, cultures, and in one word, is an objective and meta-historical criterion. While the latter is a criterion only for preferring one thing to another, without claiming that it is an absolute, ahistorical standard. It goes without saying that it is not just possible, reasonable as well to obtain a LPC unanimously, but grasping UPC is far more complex than the latter. From all this I can infer that: One who

1. believes neither in UPC nor in LPC is a full-blown relativist.

2. believes in both is a full-scale absolutist.

3. believes only in LPC, not in UPC is a moderate relativist.

For my part, I suppose that the distinction may throw new light on the quarrel between the relativist and their critics. Now, taking the distinction into consideration, let me proceed to Feyerabend.

Feyerabend, as already mentioned, admits that no value is independent of social frameworks. The presence of various moral systems bears witness to the fact that all values are based on religions, historical conditions, and metaphysical beliefs and vary from place to place or person to person. The very similar considerations are applied to our knowledge about the world. Since "the world is not directly given to us, we have to catch it through the medium of traditions which means that even the cosmological argument refers to a certain stage of competition between world-views, theories of rationality included." (AM, p233)

But it is merely one side of the coin. The other side of the coin is that he holds that there is a LPC in virtue of which one can prefer an idea, paradigm or tradition to another, it is nothing but "humanitarian considerations". This view emerges not just in the domain of ethical and human relations, but also does in his philosophy of science-i.e. in knotty problems concerning methodology, reality, scientific truth. To put it simply, true he denies an absolute, universal standard, but he doesn't really accept that all criteria/ values are on a par. He obstinately defends humanitarianism. ${ }^{28}$ And, as we have seen, according to Feyerabend humanitarian criteria are preferable to non-humanitarian ones. These are, for him, at the apex of the whole values. In light of this criterion- which is, for him, "more important than winning a war, advancing science, finding the truth"- he prefers pluralism to monism, ${ }^{29}$ democratism to totalitarianism and "theoretical

\footnotetext{
${ }^{27}$ Of course, Feyerabend, repeatedly states on several occasions another general principle: "There is only one principle that can be defended under all circumstances and in all stages of human development. It is the principle: anything goes." (AM, pp18-9) Nonetheless, in justice to Feyerabend it must be emphasized that he himself denies it. (See: SFS, p32) The extent to which his answer is reasonable is the question at stake.

${ }^{28}$ As mentioned above, he would always be willing to defend humanitarian considerations such as the right to life and freedom in any way whatever- whether by "political means" or even by "any falsehood". Let me quote from Feyerabend himself: "Neither science, nor rationalism have now sufficient authority to exclude myth, or 'primitive' thought, or the cosmologies behind the various religious creeds. Any claim to such authority is illegal and must be rejected, if necessary, by political means." (SFS, 125) Even "a truth that reigns without checks and balances is a tyrant who must be overthrown and any falsehood that can aid us in the overthrow of this tyrant is to be welcomed." (Feyerabend, 1999b, p181-2) This is not unlike Kant's idea: "Where the mass entertains the notion that the aim of certain subtle speculators is nothing less than to shake the very foundations of public welfare and morality- it seems not only prudent, but even praise worthy, to maintain the good cause by illusory arguments, rather than giving the advantage to the ... opponents." (Kant, Critique of Pure Reason, p423)

${ }^{29}$ As noted earlier, Feyerabend would always defend "pluralism"- whether "methodological pluralism" or "political pluralism". By the same token he maintains that "Protagorean relativism" is reasonable. "Because it pays attention to the pluralism of traditions and values." (AM, p226)
} 
anarchism to law-and-order alternatives". Again, on such grounds, he regards a society as advanced and, even, a scientific theory as true. This criterion is in sooth the center of gravity of Feyerabend's moral relativism.

The explanation is illustrative of the fact that Feyerabend doesn't submit to the sentence: "relativism is egalitarianism". Incidentally, Neurath's boat is here an eloquent simile against those who hold this claim. According to the simile, our knowledge is like a boat that we stand on one of its lumbers. After some time, the lumber which is under our legs is wrecked, namely, our belief is criticized. At the same time we must rebuild our boat upon the open sea. So, in such a sensitive situation what do we actually do? Obviously, we take our feet off the lumber, putting them on the safe lumber, that is to say, we must select another belief. We cannot abandon all of our beliefs and criteria, because then we would not know how to live. We are de facto compelled to choose certain beliefs among many, and to talk and live on the basis of that beliefs. As it is impossible not to put our legs on any lumber, it is impossible not to choose any criterion, form of life. On the other hand, choosing goes hand in hand with preferring; that is, the moment that one chooses a thing among many, he overtly prefer it to other alternatives, which means that, whether surreptitiously or overtly, he has a standard at the bottom of his mind. But it doesn't mean that the lumber (belief, criterion) chosen is perpetual. Maybe, the lumber is shattered at any moment. On this ground, it should not be supposed that the criterion chosen is a perpetual, everlasting.

It is also noteworthy to mention that, in Against Method, Feyerabend tells us that "Objectively speaking', i.e. independently of participation in a tradition, there is not much to choose between humanitarianism and anti-Semitism." (AM, p225) This word is only theoretically beautiful. Unless from God's point of view, I do not really see how one can speak, operate "independently of participation in a tradition"! Does Feyerabend himself do so in his whole works? Even if so, which is hardly likely, where is the man that has de facto a meta-tradition point of view? Where is the man who does not belong to any tradition? It is startling to see that he himself testifies that " "valid' standards that do not belong to any tradition might as well not exist. Even those standards that are examined in a purely intellectual fashion and in utter disregard of sociological and cosmological facts still form part of a tradition of intellectual debate". (1999b, pp207-8) The very same is true, a fortiori, of individuals, that is to say, there is no individual who is entirely free from all traditions. And Feyerabend himself, who isn't an exception of the rule, does belong to humanitarian tradition too.

Let me rephrase what I just said: Relativism, if accepted Nozick' claim, is a problem for philosophers not for scientists, not even for laymen. Since there is no one who de facto is a full-blown relativist, in the sense of being egalitarian, i.e. not being submitted to any criterion, theory or paradigm. Again I think, no one can, whether explicitly or implicitly, remain neutral regarding his milieu. ${ }^{30}$ Even scientists are de facto compelled to choose certain theories among many, otherwise they can never continue their studies. To desert the choice is to cease practicing science. Generally speaking, almost all of [full-blown moral] relativists are absolutists in disguise, as already explained as to Neurath's boat. Taking these into account, the main question is that under which classification should Feyerabend's moral relativism be classified?

\section{Conclusion}

From all these it appears that the claim "relativism is egalitarianism" is way off the mark. Feyeabend is, at least, a counterexample in this case. By the same token, he isn't, by definition, a full-blown moral relativist, but rather he is to be considered as a moderate moral relativist. This conclusion is made clearer by the fact that Feyerabend did forsake the idea of incommensurability in the last years of his intellectual life. ${ }^{31}$ By doing so, he has to choose a criterion by virtue of which can prefer a tradition to another. For him, if cultures are supposed to be compared with each other, "cultures no longer appear as sacrosanct and cannot exclusively be judged from within their own established norms. Rather, their practices can legitimately be evaluated from outside, from a humanitarian perspective." (Hoyningen-huene, 2000, p14)

It is interesting to see whenever he isn't capable of defending his claims, of answering criticisms, utilizes the shield of "humanitarian considerations" in order to reach his goals. Especially "when discussing the comparison of cultures, he tacitly admits that the success of nonscientific activities and cultures is not measurable in terms of all the virtues that

\footnotetext{
${ }^{30}$ See: Koukl, Greg. (2014), Seven things you can't do as a relativist, Salvo Magazine, Chicago, www.salvomag.com

${ }^{31}$ As far as I know, there are four Feyerabends. Roughly speaking, Feyerabend's intellectual life, in common with most eminent philosophers, may be divided into four periods: that of a "raving positivist" (AM, 1993, p257), that of a "realist" (SFS, p113), that of a dyed-in-the-wool relativist, on which he became acquainted with ideas such as Kuhn, Wittgenstein, the Anarchist and the Dadaist's ideas- the period is the longest one of his intellectual life. And finally, that of a self-composed relativist, on which he bade farewell to incommensurability and some kind of relativism. In my book, in speaking of Feyerabend's ideas precisely, one must remember this matter. This paper is directed to the third and fourth periods.
} 
characterize the best scientific theories (predictive accuracy, notably). Nevertheless, he does not shrink from the comparison: he proposes to gauge the success of cultures in terms of general humanitarian criteria such as whether they sustain lives that are meaningful and desirable to the people concerned." (Preston, 1998, pp.90-91)

Instead of the scientist who regards scientific standards as indisputable arbiter of all things, Feyerabend is of opinion that even science (scientific truth) must be judged by human criteria in that, for him, science, being a product of human mind, is merely a means to human well-being. Science is handmaid of mankind, not vice versa, the aim should be to obtain the maximum of welfare with the minimum of detriment. What good is science when it isn't the servant of human-being? Feyerabend would aspire to sacrifice "science" rather than "humanity", "scientific considerations" rather than "human ones", and "scientific truth" rather than "ethics". With these in mind, methinks, his whole philosophywhich is an amalgam of Protagorean relativism and Millian liberal utilitarianism- can be encapsulated in one sentence: I have found it necessary to deny "authority of scientific knowledge" in order to make room for "humanitarianism". ${ }^{32}$

\section{Acknowledgment}

I'm deeply indebted to Dr. G. M. Heidari, Institute of Humanities and Cultural Studies, Dr. I. Kidd, Durham University and Amin Rabinia, Texas Tech University for their worthwhile counsels. Additionally, I'd like to thank the editor and the anonymous reviewer for their valuable, constructive comments to amend the quality of the paper.

\footnotetext{
${ }^{32}$ Remember Kant's well-known quotation in the 1787 Preface: "I have found it necessary to deny knowledge in order to make room for faith. (Critique of Pure Reason, Bxxx)
} 


\section{References}

Baghramian, M. (2004). Relativism. Routledge.

Feyerabend, P. (1975). Against method (AM): Outline of an anarchistic theory of knowledge, London: Verso.

Feyerabend, P. (1993). Against Method (AM), 3rd edn, London: Verso.

Feyerabend, P. (1999b). Philosophical Papers. vol. 3: Knowledge, Science and Relativism. ed. J. Preston, Cambridge: Cambridge University Press.

Feyerabend, P. (1978). Science in a Free Society (SFS). London: NLB.

Feyerabend, P. (1980). Democracy, elitism, and scientific method. Inquiry, 23(1), 3-18.

https://doi.org/10.1080/00201748008601890

Feyerabend, P. (1987). Farewell to Reason (FR), London: Verso.

Feyerabend, P. (1995). Killing time (KT): The autobiography of Paul Feyerabend. Chicago: University of Chicago Press.

Feyerabend, P. (2001). Conquest of abundance: A tale of abstraction versus the richness of being, ed. Bert Terpestra. Chicago: University of Chicago Press.

Gonzalo, M. (Editor). (2012). Beyond Reason: Essays on the Philosophy of Paul Feyerabend, Springer Science \& Business Media.

Hoyningen-Huene, P. (2000). Paul K. Feyerabend: An Obituary. In "The Worst Enemy of Science: Essays in Memory of Paul Feyerabend". Oxford University Press, 1, 3-15.

Kant, I. (2010). Critique of Pure Reason, translated by J. M. D. Meiklejohn, The Pennsylvania State University.

Matheson, R. (2006). Husserl: A Guide for the Perplexed, Bloomsbury Academic.

Mill, J. S. (2003). On liberty, translated by David Bromwich and George Kateb, Yale University Press. https://doi.org/10.1002/9780470776018.ch3

Preston, John. (1998). Science as supermarket: 'Post-modern' themes in Paul Feyerabend's later philosophy of science. Studies in History and Philosophy of Science, 29, 425-447. https://doi.org/10.1016/S0039-3681(98)00015-6

Robert, Nozick, (2001). Invariances: The Structure of the Objective World, Cambridge, MA: Harvard University Press.

Wolf, Abraham, (1999). A history of science, technology, and philosophy in the 16th, 17th and 18th centuries, Thoemmes Press.

\section{Copyrights}

Copyright for this article is retained by the author(s), with first publication rights granted to the journal.

This is an open-access article distributed under the terms and conditions of the Creative Commons Attribution license which permits unrestricted use, distribution, and reproduction in any medium, provided the original work is properly cited. 